\title{
Effect of duodenal infusion of trans10,cis12-CLA on milk performance and milk fatty acid profile in dairy goats fed high or low concentrate diet in combination with rolled canola seed
}

\author{
Patricia Vilhena Dias de ANDRADE, Philippe SCHMIDELY*
}

Unité Mixte de Recherches "Physiologie de la Nutrition et Alimentation", Département des Sciences Animales, Institut National Agronomique, Paris-Grignon, 75231 Paris Cedex 05, France

(Received 30 March 2005; accepted 12 July 2005)

\begin{abstract}
The effect of t10,c12-C18:2 on milk production, and fatty acid (FA) profile of milk fat was studied in 8 goats infused duodenally with t10,c12-C18:2 $\left(2 \mathrm{~g} \cdot 10 \mathrm{~h}^{-1}\right)$ during 3 days, followed by a 2-day infusion of skim milk (SM). The goats were assigned to 4 diets in a factorial arrangement constituted by low $(\mathrm{L}=45 \%)$ or high $(\mathrm{H}=65 \%$ of the diet $\mathrm{DM})$ percentage of concentrate without (CS0) or with (CS20) rolled canola seed (20\% of the concentrate DM). Milk samples were collected before (basal), and during the t10,c12-C18:2 and SM infusions. The t10,c12-C18:2 in milk fat increased from undetectable basal values to an average of $0.39 \%$ of total FA in the 3rd day of t10,c12C18:2 infusion. DMI, milk yield, and the contents and yield of milk fat, protein, and lactose were similar between basal and the t10,c12-C18:2 infusion. The concentration of saturated FA with 4 to 16C did not change during the $\mathrm{t} 10, \mathrm{c} 12-\mathrm{C} 18: 2$ infusion, whereas $\mathrm{C} 18: 0$ increased, particularly in the milk fat of the CS20 group. The t10,c12-C18:2 infusion increased the t10- and t11-C18:1 (except a reduction in t11-C18:1 for the $\mathrm{H}-\mathrm{CS} 20$ group), and it decreased the c9,t11-C18:2 in milk fat, particularly for the H-CS20 group. The t10,c12-C18:2 infusion reduced the c9,t11-C18:2/t11-C18:1 ratio, particularly for the CS0 group. The results indicate that mammary lipogenesis in dairy goats was not decreased by t10,c12-C18:2, however, the desaturation of long chain FA appeared to be equally affected as in dairy cows. This reduction in the desaturase index of milk fat could have been a direct effect of t10,c12-C18:2, or mediated via an increase in t10-C18:1.
\end{abstract}

milk fatty acids / t10,c12-C18:2 infusion / canola seed / goat

\section{INTRODUCTION}

Conjugated linoleic acids (CLA) refer to a group of geometrical and positional isomers of linoleic acid (c9,c12-C18:2) with conjugated double bonds. Even though the cis9,trans 11-CLA (c9,t11-C18:2) is the most abundant isomer in dairy products [1], recent research has been focused on trans 10, cis12CLA (t10,c12-C18:2), because it decreases milk fat content (MFC) in dairy cows [2]. The c9,t11-C18:2 isomer in milk originates partly from the ruminal biohydrogenation of linoleic acid, and mostly from the desaturation of the t11-C18:1 fatty acid (FA) via $\Delta^{9}$ desaturase in the mammary gland [3].

\footnotetext{
* Corresponding author: schmidel@inapg.inra.fr
} 
The t10,c12-C18:2 in milk originates exclusively from the rumen, as it is an intermediate of the ruminal biohydrogenation of linoleic acid, particularly when high concentrate diets and/or diets rich in oil are fed [4]. The scientific interest for these FA is based on their potential effect on human health: c9,t11-C18:2 and t10,c12-C18:2 could have anti-carcinogenic effects, but t10,c12$\mathrm{C} 18: 2$ is also possibly associated with insulin resistance and a decrease in HDL-cholesterol in humans having a metabolic syndrome [5].

In dairy cows, feeding CLA supplements protected from ruminal biohydrogenation is a practical way to increase the concentration of these FA in milk and to reduce MFC [6]. Abomasal infusions of specific isomers have demonstrated that $\mathrm{t} 10, \mathrm{c} 12-\mathrm{C} 18: 2$ but not c9,t11-C18:2 was responsible for the drop in MFC [2]. In these conditions, the drop in MFC has been mainly attributed to a decrease in the yield and in the proportions of short-chain and medium-chain FA in the mammary gland due to t10,c12C18:2 [7, 8]. Additionally, abomasal infusion of high doses of t10,c12-C18:2 (7 to $\left.15 \mathrm{~g} \cdot \mathrm{d}^{-1}\right)$ but not of low doses $\left(1\right.$ to $\left.5 \mathrm{~g} \cdot \mathrm{d}^{-1}\right)$ decreased $\Delta^{9}$ desaturase activity, resulting in an increase in t11-C18:1, a decrease in c9,t11-C18:2 concentration in milk and in the oleic FA to stearic FA ratio [7, 8]. So, even thought the biological mechanisms of t10,c12-C18:2 on mammary lipid metabolism have already been explored, the influence of the diet on the response to t10,c12C18:2 infusion has rarely been investigated: Loor et al. [9] and Loor and Herbein [10], demonstrated that the inhibitory effect of t10,c12-C18:2 on the desaturation of long chain FA in cows is not alleviated by a supplemental dietary supply of unsaturated FA (oleic, linoleic or linolenic acid) or by the percentage of concentrate in the diet.

The differences between goats and cows in the MFC and milk FA profile in response to dietary lipids were recently reviewed [11, 12]. Chilliard et al. [13] and Ferlay et al. [14] indicated that a sharp increase in t10-
C18:1 concentration in the milk of goats fed different vegetable oils did not decrease MFC, on the contrary to observations in cows. These data suggest that the response of the mammary lipid metabolism in dairy goats to duodenal infusion of t10,c12$\mathrm{C} 18: 2$ could be different to that observed in cows. To our knowledge, there are no data on the effect of duodenal infusion of pure t10,c12-C18:2 on milk fat yield and composition in the dairy goat.

Therefore, the primary objective of this trial was to study the changes in MFC and in the FA profile of milk fat following the duodenal infusion of a high dose of $\mathrm{t} 10, \mathrm{c} 12$ C18:2 in dairy goats. The secondary objective was to test if these changes could be affected by diets differing by the percentage of concentrate and supplemented or not with rolled canola seed, whose combination has been shown to induce large alterations in trans-C18:1 FA, c9,t11-C18:2 and t10,c12$\mathrm{C} 18: 2$ proportions in dairy cows and goats [12].

\section{MATERIALS AND METHODS}

\subsection{Goats and diets}

Eight multiparous dairy goats fitted with ruminal and proximal T-type duodenal cannula were used. The goats were straw bedded and group-fed a basal total mixed ration (TMR) that contained on a DM basis $32 \%$ dehydrated alfalfa, $30 \%$ sugar beet pulp, $18 \%$ hay, and $20 \%$ of a commercial concentrate (Fluvialac, Agralys Aliment, Chateaudun, France). Throughout the trial, the goats were milked at 0700 and $1600 \mathrm{~h}$. The diets were fed in equal amounts (0800 and $1700 \mathrm{~h}$ ) and they were offered to provide 5$10 \%$ feed refusal.

In mid-lactation ( $65 \pm 5 \mathrm{DIM})$, the goats were placed in metabolic crates with wooden floors and they had free access to water and to a trace-mineralized salt block. The goats were used in a $2 \times 2$ factorial design constituted by a combination of the 
Table I. Ingredients and chemical composition of the experimental diets ( $n=2$ samples for each diet $)^{\mathrm{a}}$.

\begin{tabular}{|c|c|c|c|c|}
\hline \multirow{2}{*}{$\begin{array}{l}\text { Percentage of concentrate } \\
\text { Fat supplementation }\end{array}$} & \multicolumn{2}{|c|}{ Low } & \multicolumn{2}{|c|}{ High } \\
\hline & CSO & $\mathrm{CS} 20$ & CSO & $\mathrm{CS} 20$ \\
\hline \multicolumn{5}{|l|}{ Ingredients (\% DM) } \\
\hline Dehydrated alfalfa & 35.3 & 35.3 & 22.0 & 22.0 \\
\hline Grass hay & 17.7 & 17.7 & 11.0 & 11.0 \\
\hline Beet pulp & 25.0 & 25.0 & 25.0 & 25.0 \\
\hline Barley & 7.3 & 8.8 & 14.7 & 17.6 \\
\hline Corn & 8.0 & 3.5 & 15.9 & 6.9 \\
\hline Soybean meal & 4.1 & 3.1 & 8.2 & 6.1 \\
\hline Canola seed rolled & 0 & 4.1 & 0 & 8.2 \\
\hline Beet molasses & 0.6 & 0.6 & 1.2 & 1.2 \\
\hline Minerals and vitamins & 1.0 & 1.0 & 1.0 & 1.0 \\
\hline Sodium bicarbonate & 1.0 & 1.0 & 1.0 & 1.0 \\
\hline \multicolumn{5}{|l|}{ Chemical composition } \\
\hline $\mathrm{DM}, \%$ & 53.2 & 53.1 & 53.7 & 54.0 \\
\hline Fatty acids, \% DM & 1.98 & 2.82 & 2.15 & 3.34 \\
\hline $\mathrm{CP}, \% \mathrm{DM}$ & 12.4 & 12.4 & 13.3 & 13.4 \\
\hline NDF, \% DM & 50.0 & 47.0 & 37.6 & 41.9 \\
\hline $\mathrm{ADF}, \% \mathrm{DM}$ & 29.4 & 29.6 & 21.7 & 23.7 \\
\hline Starch, \%DM & 15.9 & 13.6 & 24.7 & 21.1 \\
\hline $\mathrm{NE}_{\mathrm{L}}^{\mathrm{b}}, \mathrm{kcal} \cdot \mathrm{kg}^{-1}$ of $\mathrm{DM}$ & 1377 & 1420 & 1615 & 1547 \\
\hline PDINc, $\mathrm{g} \cdot \mathrm{kg}^{-1}$ of DM & 76.5 & 77.0 & 83.0 & 83.0 \\
\hline $\mathrm{PDIE}^{\mathrm{c}} \mathrm{g} \cdot \mathrm{kg}^{-1}$ of DM & 72.5 & 74.5 & 82.0 & 80.0 \\
\hline
\end{tabular}

a Diets with (CS20) or without (CS0) canola seeds.

b Calculated from INRA (1989).

${ }^{\mathrm{c}}$ PDIN and PDIE $=$ Digestible CP in the intestine from microbial protein synthesis when the availability of fermentable $\mathrm{N}$ in the rumen is limiting, and from microbial protein synthesis when the availability of energy in the rumen is limiting, respectively (INRA, 1989).

percentage of concentrate in the DM of the TMR $($ Low $(\mathrm{L})=45 \%$ vs. High $(\mathrm{H})=65 \%)$ and the percentage of rolled canola seed (CS) in the DM of the concentrate $(\mathrm{CSO}=$ no CS vs. CS20 $=20 \%$ of CS). The forage part of the TMR was constituted by dehydrated alfalfa and grass hay in a 2:1 proportion. The 4 TMR (Tab. I) were formulated using the NEL (Net Energy for Lactation) and PDI (Digestible Protein in the Intestine) feeding systems [15] in order to meet the requirements of goats producing $4 \mathrm{~kg}$ milk and consuming $3 \mathrm{~kg}$ DM daily. The goats were switched from the basal TMR to their experimental diet during 2 weeks by pro- gressively increasing the percentage of concentrate for the goats fed the $\mathrm{H}$ diets (five days, 1 st week), and then by introducing the rolled canola seeds for the goats fed the CS diets (five days, 2nd week). The goats were fed the experimental diets for 11 weeks before starting the infusion period that consequently started at 144 DIM $( \pm 5)$.

\subsection{Infusion procedure}

The total infusion period lasted 2 weeks, and 4 different goats (1 goat for each diet) were infused each week. The infusion of t10,c12-C18:2 emulsions in skim milk was 
given during 3 consecutive days and followed by a 2 day-infusion of skim milk alone (no t10,c12-C18:2, SM). The duration of each infusion was $10 \mathrm{~h}$ per day, starting $1 \mathrm{~h}$ after the morning feeding in order to allow maximal intake after the milking, and the infusion was stopped during the night. During the infusion, feed and water were available. During the whole infusion period, the goats were machine milked in the morning, whereas the evening milking was hand milked.

The preparation of the infusions was essentially as described by Loor and Herbein [10]. To ensure a uniform infusion, the free FA form of the $\mathrm{t} 10, \mathrm{c} 12-\mathrm{C} 18: 2$ (purity 95\%, Interchim, Montluçon, France) was emulsified in skim milk the 1st day of each period of infusion in a sufficient quantity for 3 days. The t10,c12-C18:2 source was briefly heated to $50{ }^{\circ} \mathrm{C}$ to ensure a liquid form. The emulsions were then prepared by rehydrating $2400 \mathrm{~g}$ skim milk from commercial dehydrated milk powder with tap water $\left(37^{\circ} \mathrm{C}\right)$ and t10,c12-C18:2 was added to a final concentration of $10 \mathrm{~g} \cdot \mathrm{L}^{-1}$ of reconstituted milk. No glycerol or soy-lecithin was added. The emulsion was then passed through a double-stage homogenizer (Invensys APV, Evreux, France) with a first step pressure of 300 bars and a second step pressure of 30 bars and kept at $4{ }^{\circ} \mathrm{C}$ until utilization. The solution of skim milk was prepared similarly at the 4th day of the period. The emulsions were gently shacked and maintained at $37^{\circ} \mathrm{C}$ throughout the infusion period. They were infused through the duodenal cannula via a Tygon tube (B-44$4 \times, 1.6 \mathrm{~mm}$ i.d., $3.2 \mathrm{~mm}$ o.d., St Gobain, France) connected to a Watson-Marlow peristaltic pump at a rate of $20 \mathrm{~mL} \cdot \mathrm{h}^{-1} \mathrm{dur}$ ing the $10 \mathrm{~h}$. The flow of the emulsion was checked every hour. This procedure was selected to infuse approximately $2 \mathrm{~g} \mathrm{t10,c12-}$ C18:2, i.e. $0.03 \mathrm{~g} \cdot \mathrm{kg}^{-1}$ of body weight (BW: $63 \mathrm{~kg} \pm 5)$. When expressed relatively to DMI, the actual dose was approximately $0.72 \mathrm{~g} \mathrm{t10}, \mathrm{c} 12-\mathrm{C} 18: 2 \cdot \mathrm{kg}^{-1}$ of DMI, a value in the upper range of the doses of pure t10,c12-C18:2 (0.05 to $0.75 \mathrm{~g} \mathrm{CLA} \cdot \mathrm{kg}^{-1}$ of
DMI) that significantly inhibited milk fat synthesis in cows $[7,10,16]$.

\subsection{Sampling, measurement and analysis}

Two samples of the diets were collected at the end of the period of adaptation to the experimental diets and just before the first period of infusion. One aliquot of each sample was immediately stored at $-20{ }^{\circ} \mathrm{C}$ and later freeze-dried $(72 \mathrm{~h})$ and ground $(1 \mathrm{~mm})$ before FA analysis. The other aliquot was dried in a force-air oven at $90^{\circ} \mathrm{C}$, then ground and stored at room temperature until analysis. The NDF and ADF contents of the diets were determined according to the method of Van Soest et al. [17]. Total N of the diets was determined by the microKjeldahl technique. The starch content of the diets was determined by IR spectrophotometry in the laboratory of the feed manufacturer INZO (Château-Thierry, France).

During each period of infusion, the DMI was recorded daily. The individual morning and evening samplings of milk $(30 \mathrm{~mL}$ per milking) were started the evening before the 1st day of t10,c12-C18:2 infusion and they ended the morning following the last day of SM infusion. Evening and morning milk samples collected before the t10,c12C18:2 infusion were used as the control (basal values) to test the effect of $t 10, \mathrm{c} 12$ C18:2 infusion. The samples collected during SM infusion were used to study the reversal changes in mammary metabolism after the cessation to the exposure to t10,c12-C18:2, with a possible carry-over effect of t10,c12-C18:2 infusion during SM infusion. Two individual aliquots of each milk samples $(30 \mathrm{~mL})$ were collected. The 1 st aliquot containing Bronopol was stored at $4{ }^{\circ} \mathrm{C}$ until analysis of fat, $\mathrm{CP}$ and lactose. The 2nd aliquot without preservative was stored at $-20{ }^{\circ} \mathrm{C}$ until analysis of milk fat content and fatty acid profile. Two samples of the t10,c12-C18:2 and SM emulsions were taken immediately after their preparation and they were stored at $-20{ }^{\circ} \mathrm{C}$ until analysis. 
Milk total solids were determined by $72 \mathrm{~h}$ freeze-drying. Milk fat, protein and lactose were analyzed by infrared analysis (Milkoscan; Foss Electric, Hillerød, Denmark). Moreover, because milk fat content could be low during t10,c12-C18:2 infusion, the milk fat content of the freeze-dried samples was also determined by chloroform-methanol extraction (2/1) using a Soxtec apparatus 1041 (Tecator, France). The correlation between the two methods was good with $r^{2}=0.97$.

The lipid content of the diet was extracted according to Folch et al. [18]. Milk FA were extracted twice from $1 \mathrm{~mL}$ of milk with ethanol: $12 \mathrm{~N} \mathrm{HCl}$ :hexane $(0.4 /$ $0.1 / 7 \mathrm{~mL})$ and then $7 \mathrm{~mL}$ hexane. After filtration, the solution was evaporated. The FA were solubilized in $2 \mathrm{~mL}$ hexane and then evaporated. Hexane was then added to obtain a concentration of 10 to $14 \mathrm{mg}$ FA. $\mathrm{mL}^{-1}$ hexane and $1 \mathrm{~mL}$ of internal standard solution (tricosanoic acid, C23:0, $0.5 \mathrm{mg} \cdot \mathrm{mL}^{-1}$ ) was added to $1 \mathrm{~mL}$ of the solution. The FA were methylated at room temperature with a methanolic boron trifluoride solution $(14 \%, \mathrm{wt} / \mathrm{vol})$. Methyl esters of FA were then recuperated in hexane.

Samples of $1 \mu \mathrm{L}$ hexane containing methyl-esters from milk or feed samples were injected by an auto sampler into a Varian Chromopack CP 3800 gas chromatograph equipped with a flame ionization detector (Varian SA, Les Ulis, France). Methyl esters were separated on a $100 \mathrm{~m} \times$ $0.25 \mathrm{~mm}$ i.d. fused silica capillary column (CP-Sil 88, Interchim, Montluçon, France). The carrier gas was ultra pure helium with a flow of $1 \mathrm{~mL} \cdot \mathrm{min}^{-1}$. Injector and detector temperatures were maintained at $250{ }^{\circ} \mathrm{C}$. The split ratio in the injector was 20:1. The initial oven temperature was $50{ }^{\circ} \mathrm{C}$ (for $1 \mathrm{~min}$ ), increased $10{ }^{\circ} \mathrm{C} \cdot \mathrm{min}^{-1}$ to $170{ }^{\circ} \mathrm{C}$ (held for $78 \mathrm{~min}$ ) and increased $5^{\circ} \mathrm{C} \cdot \mathrm{min}^{-1}$ to $220{ }^{\circ} \mathrm{C}$ (held for $15 \mathrm{~min}$ ). Individual FA were identified by comparison of retention time to those of pure FA methyl-ester standards of C4:0, C6:0, C8:0, C10:0, C11:0, C12:0, C13:0, C14:0, ai C15:0, c9-C14:1,
C15:0, C16:0, c9-C16:1, C17:0, C18:0, t9C18:1,t11-C18:1, c6-C18:1, c9-C18:1, c11C18:1, C19:0, t9,t12-C18:2, c9,c12-C18:2, c9,t11-C18:2, t10,c12-C18:2, c6,c9,c12C18:3, c9,c12,c15-C18:3 (Supelco Inc, Bellefonte, USA). The t6+7+8-C18:1 and t10-C18:1 were identified by order of elution. Correction factors for the possible loss of volatile short-chain FA (C4:0 to C8:0) during analysis were not calculated, which may explain the low values for $\mathrm{C} 4: 0$ to $\mathrm{C} 8: 0$ percentages (see results).

\subsection{Statistical analysis}

Data for DMI, milk yield and composition, and milk FA concentration obtained during the last two days of t10,c12-C18:2 (day 2 and 3) were averaged per goat, as well as the data obtained during the 2 days of skim milk infusion (SM, day 4 and 5). Data obtained before infusion (basal), during the infusion of $\mathrm{t} 10, \mathrm{c} 12-\mathrm{C} 18: 2$, and during the infusion of skim milk (SM) were analyzed as a factorial design with repeated measures using the MIXED Procedure of SAS [19]. The model included the percentage of concentrate ( $\mathrm{L}$ vs. $\mathrm{H}$, fixed effect), canola seed (CS20 vs. no CS, fixed effect), percentage of concentrate $\times$ canola seed interaction (fixed effect), time (fixed effect), percentage of concentrate $\times$ time interaction (fixed effect), canola seed $\times$ time interaction (fixed effect), percentage of concentrate $\times$ canola seed $\times$ time interaction (fixed effect), goat (random effect) and residual error. First order autoregressive [AR(1)] was used as the covariance structure for repeated measurements. The effects of infusion were associated with the effect of time (repeated measures for a same goat, with time $=0$ for basal, time $=1$ for $\mathrm{t} 10, \mathrm{c} 12$ $\mathrm{C} 18: 2$ infusion, and time $=2$ for SM infusion). The relevant comparison for the effect of $\mathrm{t} 10, \mathrm{c} 12-\mathrm{C} 18: 2$ infusion was time $=1$ (t10,c12-C18:2 infusion) vs. time $=0$ (basal), whereas the comparison between time $=1$ vs. time $=2$ (SM infusion) determined eventual carry-over effects of t10,c12-C18:2 during skim milk infusion. 
The data for each FA intake were analyzed in a factorial design using the GLM procedure of SAS [19], with percentage of concentrate, canola seed, and interaction between percentage of concentrate and canola seed as fixed factors.

\section{RESULTS}

\subsection{Diet composition}

As expected, when compared to the $\mathrm{L}$ diets, the $\mathrm{H}$ diets had significantly lower NDF and ADF contents, and they had significantly higher NEL values (Tab. I). By design, the diets with CS had significantly higher FA contents than the other diets. Unexpectedly, all diets had low CP and PDI values, probably because of an overestimation of the $\mathrm{CP}$ content of the ingredients when the diets were calculated. They were all below PDI requirements [15] and slightly below NRC requirements [20]. The fatty acid profile of the diets is presented in Table II. When compared to the CSO diets, the CS20 diets had higher oleic acid content and lower linoleic and linolenic acid contents. The concentrations of total transC18:1, and c9,t11-C18:2 were low. The quantity of c9,t11-C18:2 fed was conse- quently low and it ranged between 6.55 and $15.6 \mu \mathrm{g} \cdot \mathrm{g}^{-1}$ of DM.

\subsection{Fatty acid profile of the emulsions}

The emulsions of t10,c12-C18:2 infused contained almost exclusively t10,c12-C18:2 isomer, with some traces of $\mathrm{C} 14: 0$ and C16:0. No c9,t11-C18:2 isomer was detectable. The SM solutions only contained very small traces of lipids, which were insufficient to determine their FA profile.

\subsection{DMI, FA intake, milk yield and composition}

During the infusions, the health of the goats was good. Rectal temperature at the end of each day of infusion was $39 \pm 0.4{ }^{\circ} \mathrm{C}$ and no evident sign of any pain was apparent. The actual rates of infusion were $20.4 \pm$ $0.6 \mathrm{~mL} \cdot \mathrm{h}^{-1}$ and $19.8 \pm 0.6 \mathrm{~mL} \cdot \mathrm{h}^{-1}$ in periods 1 and 2 respectively, which was very close to the target flow.

Before the infusion, the goats fed the HCSO diets had the lowest value for raw milk yield, fat yield, protein yield and lactose yield (Tab. III): consequently when compared to the L diets, the goats fed the $\mathrm{H}$ diets had lower DMI, lower raw milk yield, lower

Table II. Fatty acid profile of experimental diets ( $n=2$ samples/diet $)^{\mathrm{a}}$.

\begin{tabular}{lcccc}
\hline Percentage of concentrate & \multicolumn{2}{c}{ Low } & High \\
\hline Fat supplementation & CS0 & CS20 & CS0 & CS20 \\
\hline Fatty acids & & \% of total fatty acids & 0.10 \\
\hline $\mathrm{C}_{14: 0}$ & 0.34 & 0.17 & 0.20 & 8.45 \\
$\mathrm{C}_{16: 0}$ & 17.89 & 9.95 & 16.39 & 0.32 \\
c9-C $16: 1$ & 0.40 & 0.32 & 0.27 & 1.62 \\
$\mathrm{C}_{18: 0}$ & 1.90 & 1.69 & 1.87 & 48.95 \\
$\mathrm{c} 9-\mathrm{C}_{18: 1}$ & 14.96 & 43.97 & 20.48 & 0.03 \\
Total trans-C & $0.03: 1$ & 0.03 & 0.02 & 27.22 \\
$\mathrm{c} 9, \mathrm{c} 12-\mathrm{C}_{18: 2}$ & 40.26 & 26.49 & 47.10 & 0.02 \\
$\mathrm{c} 9, \mathrm{t} 11-\mathrm{C}_{18: 2}$ & 0.08 & 0.07 & 0.05 & 9.56 \\
$\mathrm{c} 9, \mathrm{c} 12, \mathrm{c} 15-\mathrm{C}_{18: 3}$ & 20.90 & 13.36 & 11.45 & \\
\hline
\end{tabular}

a Diets with (CS20) or without (CSO) canola seeds. 


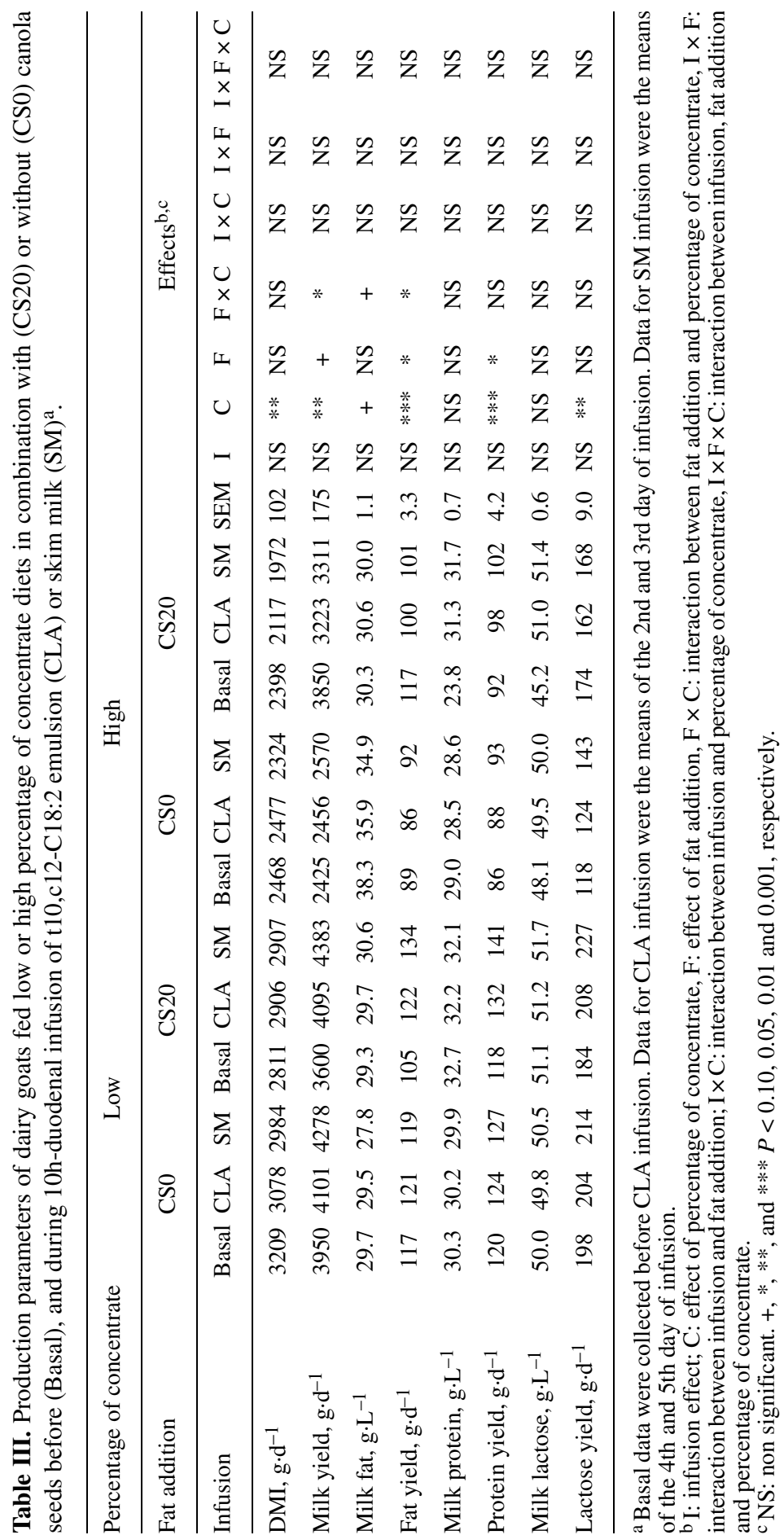


Table IV. Fatty acid intake of dairy goats fed low or high percentages of concentrate diets in combination with (CS20) or without (CS0) canola seedsa.

\begin{tabular}{|c|c|c|c|c|c|c|c|c|}
\hline \multirow{2}{*}{$\begin{array}{l}\text { Percentage of concentrate } \\
\text { Fat supplementation }\end{array}$} & \multicolumn{2}{|c|}{ Low } & \multicolumn{2}{|c|}{ High } & \multirow[b]{2}{*}{ SEM } & \multicolumn{3}{|c|}{ Effects ${ }^{b, c}$} \\
\hline & CSO & CS20 & CSO & CS20 & & $\mathrm{C}$ & $\mathrm{F}$ & $\mathrm{F} \times \mathrm{C}$ \\
\hline \multicolumn{9}{|l|}{ Fatty acid } \\
\hline $\mathrm{C}_{14: 0}$ & 0.22 & 0.13 & 0.11 & 0.08 & 0.01 & $* * *$ & $* *$ & $*$ \\
\hline $\mathrm{C}_{16: 0}$ & 11.37 & 7.89 & 8.70 & 6.77 & 0.04 & $*$ & $*$ & NS \\
\hline c9- $\mathrm{C}_{16: 1}$ & 0.25 & 0.25 & 0.14 & 0.26 & 0.01 & $*$ & $*$ & $*$ \\
\hline $\mathrm{C}_{18: 0}$ & 1.21 & 1.34 & 0.99 & 1.30 & 0.04 & NS & NS & NS \\
\hline c9- $\mathrm{C}_{18: 1}$ & 9.5 & 34.9 & 10.9 & 39.2 & 2.72 & NS & $* * *$ & NS \\
\hline $\mathrm{c} 9, \mathrm{c} 12-\mathrm{C}_{18: 2}$ & 25.6 & 21.0 & 25.0 & 21.8 & 0.76 & NS & NS & NS \\
\hline $\mathrm{c} 9, \mathrm{c} 12, \mathrm{c} 15-\mathrm{C}_{18: 3}$ & 13.3 & 10.6 & 6.1 & 7.7 & 0.62 & $* *$ & NS & $*$ \\
\hline Total & 63.5 & 79.3 & 53.1 & 80.0 & 2.85 & NS & $* *$ & NS \\
\hline
\end{tabular}

a Data presented are the means before the t10,c12-C18:2 infusion.

${ }^{b} \mathrm{C}$ : effect of percentage of concentrate, $\mathrm{F}$ : effect of fat addition, $\mathrm{F} \times \mathrm{C}$ : interaction between fat addition and percentage of concentrate.

${ }^{c}$ NS: non significant. $*, * *$, and $* * * P<0.05,0.01$ and 0.001 , respectively.

fat yield, lower protein yield, and lower lactose yield. Feeding CS20 diets increased raw milk yield, and fat yield only when goats were fed $\mathrm{H}$ diets (interaction $\mathrm{F} \times \mathrm{C}$ : $P<0.05)$. Before the infusion, total FA intake and c9-C18:1 intake were higher for the goats fed the CS20 diets than for the goats fed the CSO diets (Tab. IV). The goats fed the L diets had higher $\mathrm{c} 9, \mathrm{c} 12, \mathrm{c} 15-\mathrm{C} 18: 3$ intake than the goats fed the $\mathrm{H}$ diets.

The data on DMI, raw milk yield, MFC and yield, milk protein content and yield, and milk lactose content and yield, obtained during t10,c12-C18:2 infusion did not differ from basal data obtained before any infusion. The DMI, the milk yield and the milk composition were not affected by the interaction between the $\mathrm{t} 10, \mathrm{c} 12-\mathrm{C} 18: 2 \mathrm{infu}-$ sion and the dietary factors (Tab. III).

\subsection{Milk fatty acid profiles}

Before the infusion (Tab. V), when compared to the goats fed the L diets, the goats fed the $\mathrm{H}$ diets tended to have higher concentrations of $\mathrm{C} 4: 0$ and $\mathrm{C} 6: 0$ in milk, and they had significantly higher concentrations of C18:0, all trans-FA with $18 \mathrm{C}$ units, and $\mathrm{c} 9, \mathrm{t} 11-\mathrm{C} 18: 2$; this occurred at the expense of the concentration of saturated FA between 11 and $17 \mathrm{C}$ units, and of c9-C14:1, c9-C16:1, c9,c12-C18:2 and c9,c12,c15-C18:3 in milk fat. The ratios of c9-C16:1/C16:0, c9-C18:1/C18:0 and c9,t11-C18:2/t11-C18:1 were reduced in the milk fat of the goats fed the $\mathrm{H}$ diets (Tab. VI). Before the infusion, when compared to the goats fed the CSO diets, the goats fed the CS20 diets had higher concentrations of $\mathrm{C} 18: 0$, all trans-FA with $18 \mathrm{C}$ units, c9-C18:1, c9,t11-C18:2, and c9,c12,c15C18:3; this occurred at the expense of the concentration of saturated FA with 11 to $17 \mathrm{C}$ units and of $\mathrm{c} 9-\mathrm{C} 14: 1, \mathrm{c} 9-\mathrm{C} 16: 1$ in milk fat. The ratios of $\mathrm{c} 9-\mathrm{C} 16: 1 / \mathrm{C} 16: 0, \mathrm{c} 9$ C18:1/C18:0 and c9,t11-C18:2/t11-C18:1 were reduced in the milk fat of the goats fed the CS20 diets (Tab. VI). The goats fed the $\mathrm{H}-\mathrm{CS} 20$ diet tended to have the highest concentrations of $\mathrm{t} 9-\mathrm{C} 18: 1$ and $\mathrm{t} 10-\mathrm{C} 18: 1$ in milk fat (interaction $\mathrm{F} \times \mathrm{C}: P<0.10$ ).

Before the infusion, the t10,c12-C18:2 was not detectable in milk fat (Fig. 1), except at a very low level in the milk from one goat fed the L-CSO diet. It became detectable in milk fat at the first evening 


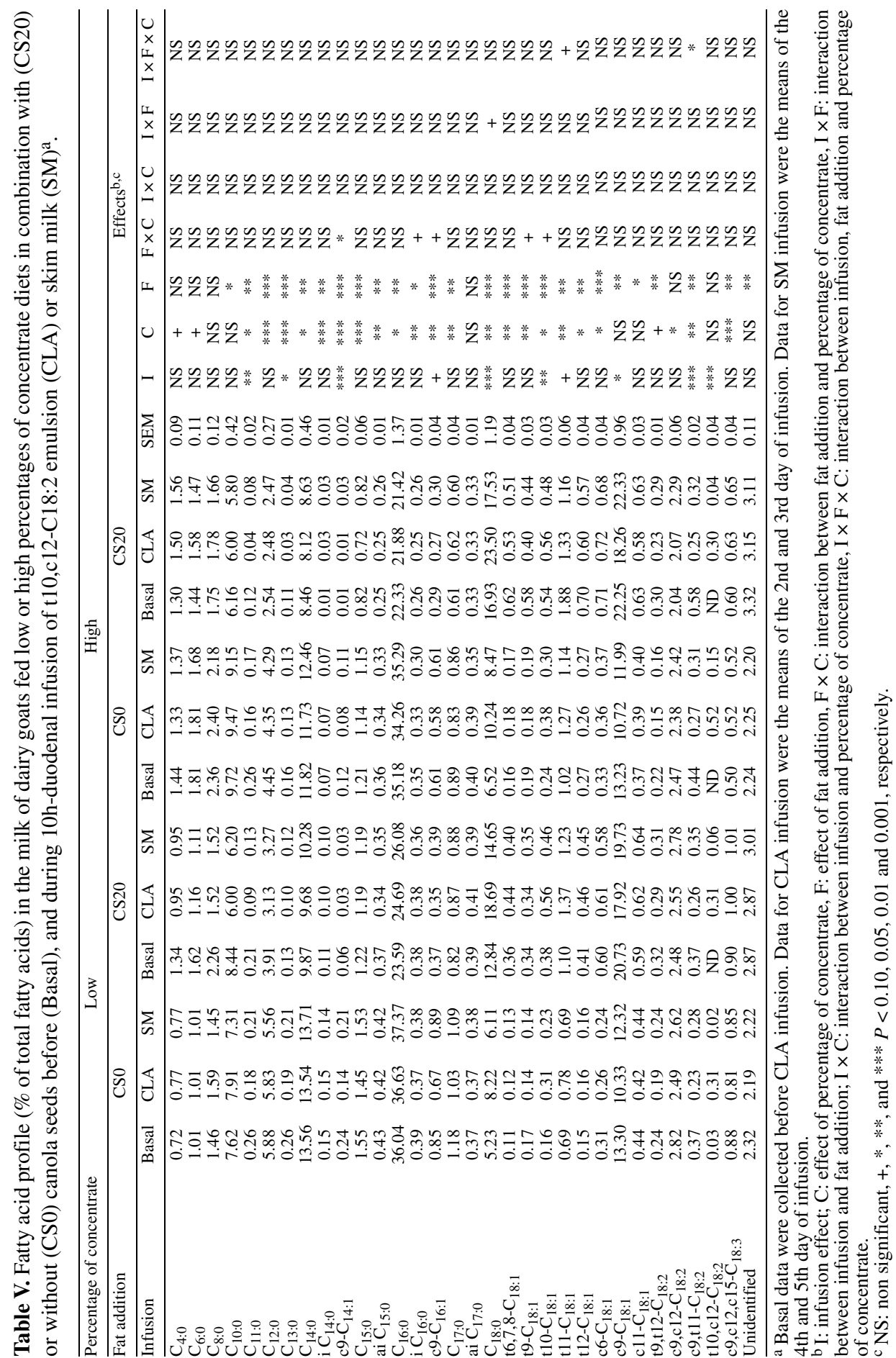




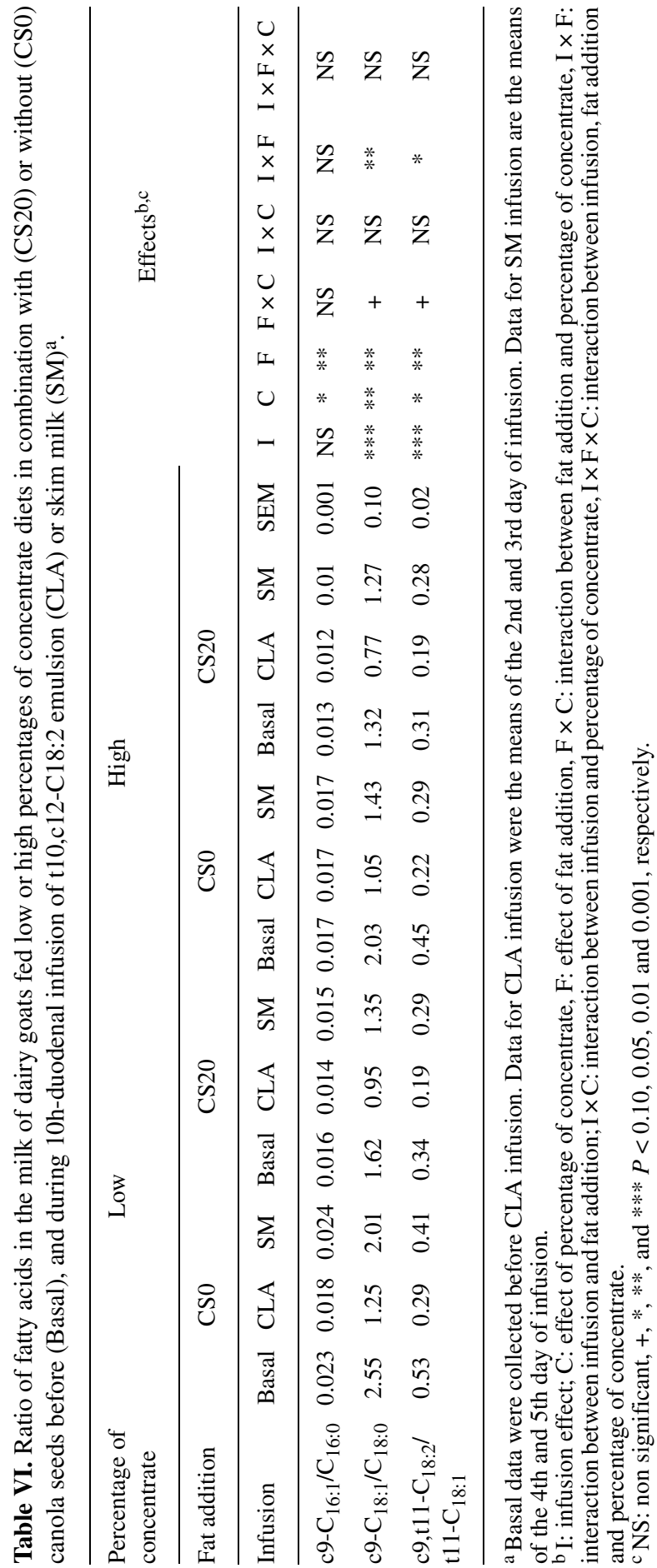



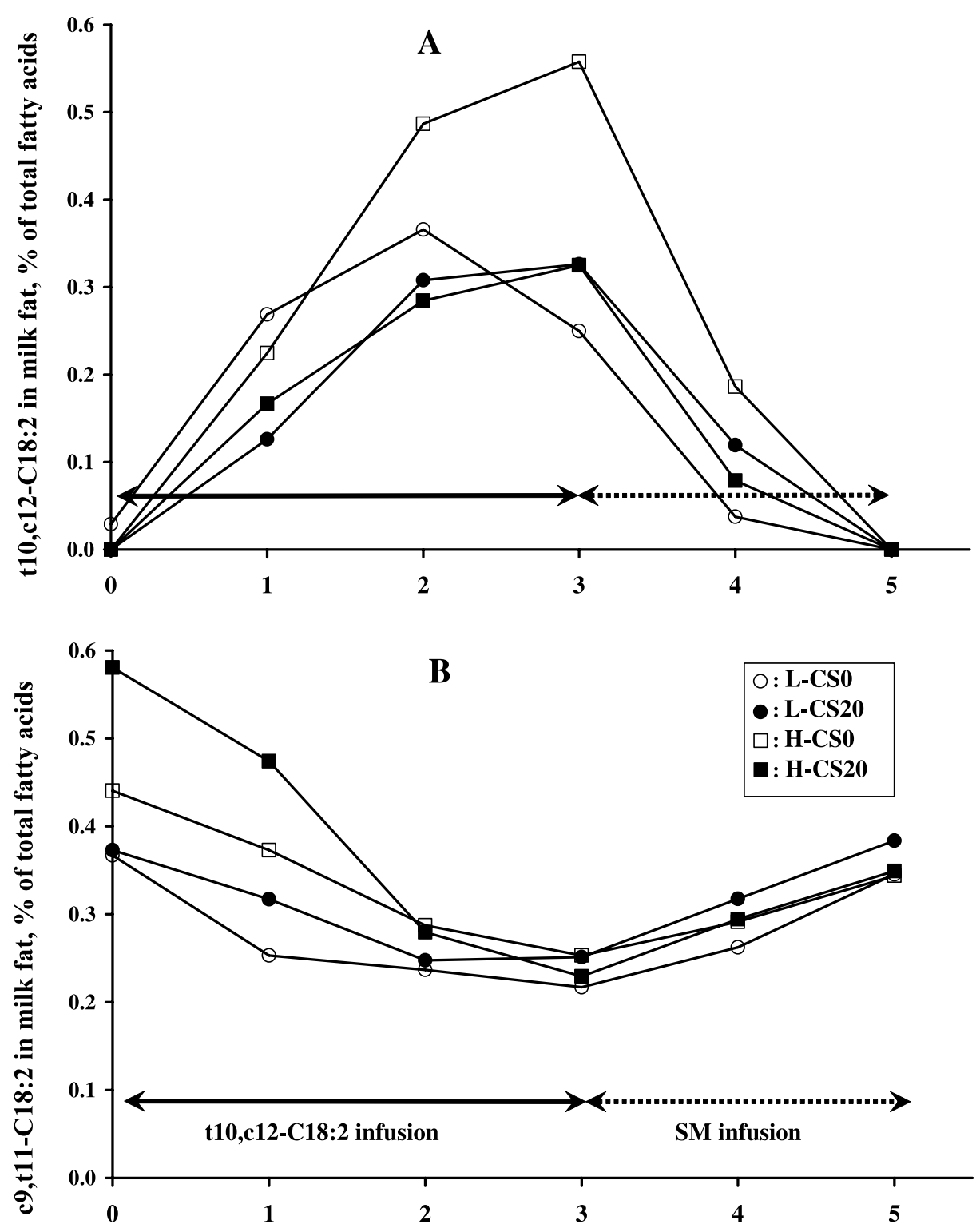

Days of infusion

Figure 1. Temporal pattern of the proportion of t10,c12-C18:2 (panel A) and c9,t11-C18:2 (panel B) in the milk from goats fed low (L: $\bullet, O)$ or high (H: $\mathbf{}, \square)$ percentage of concentrate diets in combination with (CS20: $\bullet, \mathbf{\square})$ or without (CS0: $\bigcirc, \square)$ canola seeds and infused into the duodenum during $10 \mathrm{~h}$ with t10,c12-C18:2 or skim milk (SM). SEM were 0.04 and $0.02 \%$ for the $\mathrm{t} 10, \mathrm{c} 12-\mathrm{C} 18: 2$ and c9,t11-C18:2, respectively. 
milking, and it progressively increased until the 3rd day of the t10,c12-C18:2 infusion to reach an average value of $0.39 \%$ (SEM = 0.1) of total FA (Fig. 1), which was not affected by dietary factors (Tab. V). Its concentration decreased thereafter, to be below the detectable level at the 2nd day of the SM infusion. The average yield of t10,c12C18:2 during the infusion (day 2 and 3 ) was $0.35 \mathrm{~g} \cdot \mathrm{d}^{-1}($ SEM $=0.02)$, and it was not affected by dietary factors. The comparison of the amount of t10,c12-C18:2 infused and its secretion in milk indicated that the transfer efficiency of t10,c12-C18:2 was $17.8 \%$ $(\mathrm{SEM}=2.1)$. The concentration of $\mathrm{c} 9, \mathrm{t} 11$ C18:2 in milk fat was progressively reduced during the $\mathrm{t} 10, \mathrm{c} 12-\mathrm{C} 18: 2$ infusion to an average value of $0.25 \%(\mathrm{SEM}=0.05)$ of total FA (Fig. 1). Its decrease was the highest for the goats fed the H-CS20 diets (interaction $\mathrm{I} \times \mathrm{F} \times \mathrm{C}: P<0.05$ ). At the end of the SM infusion, c9,t11-C18:2 remained below its basal value, particularly for the goats fed the H-CS20 diets.

The concentration of even-numbered saturated FA with 4 to $16 \mathrm{C}$ units was not affected by the t10,c12-C18:2 infusion or by the interaction between the t10,c12C18:2 and the dietary factors (Tab. V). The C18:0 concentration in milk fat increased during the t10,c12-C18:2 infusion, particularly for the goats fed the CS20 diets (interaction $\mathrm{I} \times \mathrm{F}: P<0.05)$ that had the highest concentration of C18:0 before infusion (effect of fat: $P<0.01$ ). During the SM infusion, its concentration was greater than the basal value in all groups. The concentration of c9-C14:1, c9-C16:1 $(P<0.10)$, and c9C18:1 decreased during t10,c12-C18:2 infusion, independently of their basal values. The concentration of these 3 monounsaturated FA returned to their basal value by the end of the SM infusion. The concentration of t10-C18:1 increased progressively during the t10,c12-C18:2 infusion (Fig. 2). By the end of the SM infusion, the concentration of t10-C18:1 was higher than its basal value, except for the goats fed the $\mathrm{H}$ CS20 diet. The concentration of t11-C18:1 tended to increase $(P<0.10)$ during the
t10,c12-C18:2 infusion (Fig. 2), except for the goats fed the H-CS20 diet (interaction $\mathrm{I} \times \mathrm{F} \times \mathrm{C}: P<0.10$ ) that had the highest concentration for this FA before infusion.

The concentration of odd-numbered FA with 11 or $13 \mathrm{C}$ units decreased during the t10,c12-C18:2 infusion and it remained below the basal value at the end of the SM infusion.

The ratios of $\mathrm{c} 9-\mathrm{C} 18: 1 / \mathrm{C} 18: 0$ and c9,t11-C18:2/t11-C18:1 were reduced by the t10,c12-C18:2 infusion (Tab. VI), and their values at the end of the SM infusion were lower than those before the infusion. The decrease in the ratios of $\mathrm{c} 9-\mathrm{C} 18: 1 /$ C18:0 and c9,t11-C18:2/t11-C18:1 during the $\mathrm{t} 10, \mathrm{c} 12-\mathrm{C} 18: 2$ infusion was higher for the goats fed the $\mathrm{CSO}$ diets than for the goats fed the CS20 diets (interaction I $\times \mathrm{F}: P<$ 0.01 and $P<0.05$ for $\mathrm{c} 9-\mathrm{C} 18: 1 / \mathrm{C} 18: 0$ and c9,t11-C18:2/t11-C18:1, respectively). During the $110, \mathrm{c} 12-\mathrm{C} 18: 2$ infusion, the ratio of c9,t11-C18:2/t11-C18:1 and the concentration of t10-C18:1 in milk fat were inversely related (Fig. 3) with a within-goat relationship ( $n=8$ goats) calculated using the GLM procedure of SAS [19] as:

c9,t11-C18:2/t11-C18:1 = 0.69 $( \pm 0.067)-$ $1.30( \pm 0.226) \times \mathrm{t} 10-\mathrm{C} 18: 1, \mathrm{R} 2=0.88$, $\mathrm{RMSE}=0.06$, which indicated that $\mathrm{c} 9, \mathrm{t} 11-$ C18:2/t11-C18:1 in milk fat decreased by 0.13 for each $0.10 \%$ increase in the proportion of t10-C18:1 in milk fat.

\section{DISCUSSION}

In our study, the goats fed the H-CSO diet had the lowest milk yield, which is in contrast to data reviewed by Schmidely and Sauvant [11]. This was due to one goat that had a very low milk production from the middle of the trial, without any DMI decrease. Possibly, this could have partly affected the study of interaction between t10,c12-C18:2 infusion and the 4 diets, but we are not aware of data reporting the effect of raw milk yield on the response to t10,c12-C18:2 infusion. 

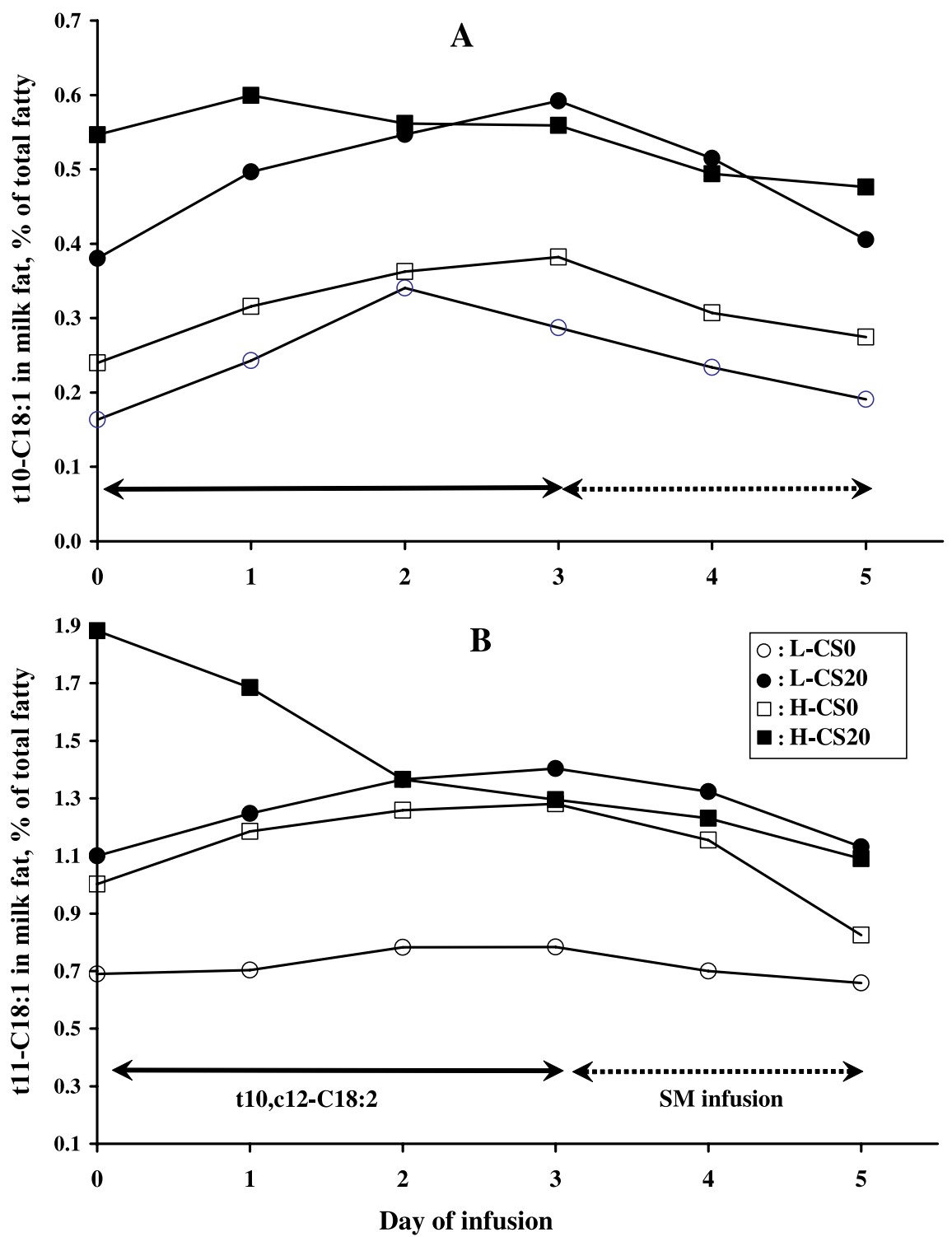

Figure 2. Temporal pattern of the proportion of t10-C18:1 (panel A) and t11-C18:1 (panel B) in the milk fat from goats fed low (L: $\bullet, O)$ or high $(\mathrm{H}: \mathbf{\square}, \square)$ percentage of concentrate diets in combination with (CS20: $\bullet, \mathbf{\square})$ or without $(\mathrm{CS} 0: \bigcirc, \square)$ canola seeds and infused into the duodenum during $10 \mathrm{~h}$ with t10,c12-C18:2 or skim milk (SM). SEM were 0.03 and $0.06 \%$ for the t10-C18:1 and t11-C18:1 respectively.

Increasing the percentage of concentrate in our study decreased medium-chain saturated FA (11 to $16 \mathrm{C}$ units), and it increased t6+7+8-C18:1 as well as t9 to t12-C18:1, and c9,t11-C18:2 as previously observed in dairy goats $[12,21]$. Feeding CS20 diets in our trial decreased $\mathrm{C} 10: 0$ to $\mathrm{C} 14: 0$ and $\mathrm{C} 16: 0$ and it increased all trans monoene 


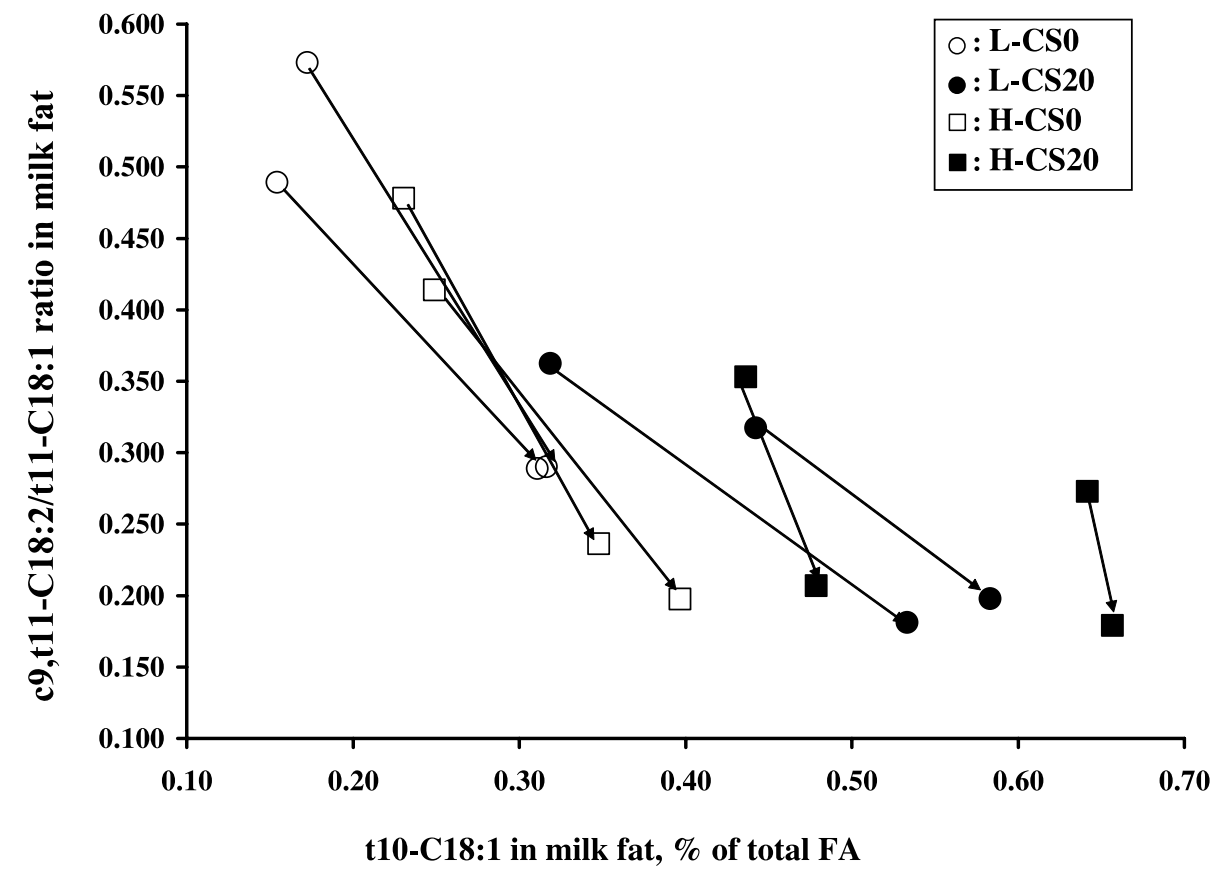

Figure 3. Within-goat relation between $\mathrm{c} 9, \mathrm{t} 11-\mathrm{C} 18: 2 / \mathrm{t} 11-\mathrm{C} 18: 1$ and $\mathrm{t} 10-\mathrm{C} 18: 1$ percentage in the milk of goats fed low (L: $\bullet, \bigcirc)$ or high $(\mathrm{H}: \mathbf{\square}, \square)$ percentage of concentrate diets in combination with (CS20: $\bullet$ ) or without (CS0: $\bigcirc, \square)$ canola seeds and infused into the duodenum during $10 \mathrm{~h}$ with t10,c12-C18:2. Each couple of points represents the data by goat before the start of infusion (Basal, start of the arrow) and for the t10,c12-C18:2 infusion (end of the arrow).

FA with $18 \mathrm{C}$ units (especially t10 and t11$\mathrm{C} 18: 1)$ as well as $\mathrm{c} 9, \mathrm{t} 11-\mathrm{C} 18: 2$, in line with the data reviewed by Chilliard et al. [13] and Chilliard and Ferlay [12].

The primary aim of this trial was to study the possible changes in MFC and in the FA profile of milk fat during the t10,c12-C18:2 infusion in dairy goats, and the second objective was to test if these changes could be affected by diets differing by the percentage of concentrate and fat supplementation. In dairy cows, the abomasal infusion of mixtures of CLA [22] or of pure isomers [23] has been used to bypass the biohydrogenation of CLA during the fermentation process in the rumen. It has been shown to be a convenient way to determine that t10,c12-C18:2 was the effective isomer to reduce MFC [2, 24]. To our knowledge, no comparable study has been conducted in dairy goats, a species which is known to have some particularities for FA metabolism in the mammary gland [11, 13]. In our conditions, when compared to the basal data obtained before starting the CLA infusion, no effect of the duodenal infusion of a high dose of t10,c12-C18:2 was observed on the MFC or the fat yield, despite a high t10,c12-C18:2 concentration in the milk (see below). Some methodological considerations may be addressed that could partially explain such differences. Abomasal continuous t10,c12-C18:2 infusion was performed for 20 to $24 \mathrm{~h}$ in most of the studies on cows $[2,8,10]$ in contrast to our trial where a discontinuous infusion was selected. However, in some studies with cows [24, 
$25]$, the $110, \mathrm{c} 12-\mathrm{C} 18: 2$ infusion was discontinuous with 4 periods of infusion of unknown duration separated by an interval of $6 \mathrm{~h}$, but the decrease in MFC and in fat yield was similar to that observed with continuous infusion. Moreover, we also observed a $17.8 \%$ transfer efficiency of $\mathrm{t} 10, \mathrm{c} 12$ C18:2 into milk fat, which is close to the value of $21.7 \%$ obtained by de Veth et al. [25] when pooling data from six different studies. This suggests that the availability of t10,c12-C18:2 in the mammary gland was high in our trial. Indeed, a high mammary gland extraction ratio (80\%) of $\mathrm{t} 10, \mathrm{c} 12-$ C18:2 from plasma triglyceride and free $F A$ was observed during the t10,c12-C18:2 infusion in cows [10]. Practically, the average concentration of $\mathrm{t} 10, \mathrm{c} 12-\mathrm{C} 18: 2$ in milk fat during days 2 and 3 of the infusion was $0.39 \%$ of total FA, with a maximal value of $0.53 \%$ of total FA in the milk fat of the goats fed the H-CSO diet. This average concentration was in the range of the concentrations of $\mathrm{t} 10, \mathrm{c} 12-\mathrm{C} 18: 2$ that induced a dramatic decrease in the milk fat synthesis in dairy cows $[7,10,16]$.

When compared with dairy cows, the milk FA composition was differently altered by the t10,c12-C18:2 infusion in goats. In dairy cows, the decrease in the MFC and in the fat yield were largely related to a decrease in the yield and in the percentage of shortto medium chain saturated FA [2]. The highest decreases in short to medium-chain saturated FA were observed with the highest doses of t10,c12-C18:2 infused [7, 8, 26]. However, in our trial no effect on MFC was observed whatever the diet, probably because the synthesis of even-numbered saturated FA with 4 to $16 \mathrm{C}$ was not decreased despite a high t10,c12-C18:2 concentration in milk fat. Recently, Baumgard et al. [16] demonstrated that the mechanism by which $\mathrm{t} 10, \mathrm{c} 12-\mathrm{C} 18: 2$ decreased the secretion of short to medium-chain FA in the milk of cows involved a reduction in the mRNA abundance for the genes encoding acetyl-CoA Carboxylase, and Fatty Acid Synthetase, which are two key enzymes in de novo synthesis by the mammary gland.
Our results indicate that the activity of these two enzymes was probably not reduced by the duodenal infusion of $2 \mathrm{~g}$ per day of t10,c12-C18:2. Goats fed $11 \mathrm{~g}$ per day of rumen-protected t10,c12-C18:2 [27] had higher concentration of t10,c12-C18:2 in milk fat $(2.5 \% \mathrm{wt} / \mathrm{wt})$ than those observed in our study, and they had lower concentration of FA with 10 to $14 \mathrm{C}$ units, but the changes in the MFC and in the fat yield were not reported. This suggests that, when compared to cows, the biochemical pathways of de novo lipogenesis in the mammary gland of the goat could necessitate higher concentrations of t10,c12-C18:2 in milk fat to be altered.

In the mammary gland of ruminants [13], monounsaturated FA arise either from direct uptake from the blood stream, or from desaturation of saturated FA via a $\Delta^{9}$ desaturase (Stearoyl-CoA Desaturase). The C14:0, C16:0, C18:0 but also t11-C18:1 FA are substrates for $\Delta^{9}$ desaturase in the mammary gland, introducing a double bond to produce c9-C14:1, c9-C16:1, c9-C18:1, and c9,t11-C18:2 respectively [3], which are essential to maintain milk fat fluidity and secretion. Consequently, product to substrate ratios of c9-C14:1/C14:0, c9C16:1/C16:0, c9-C18:1/C18:0, and c9,t11C18:2/t11-C18:1 represent a desaturase index and they serve as a proxy for $\Delta^{9}$ desaturase activity. In dairy cows, the infusion of a high dose $[7,16,26]$ but not of a low dose $[7,8,25]$ of $\mathrm{t} 10, \mathrm{c} 12-\mathrm{C} 18: 2$ reduced desaturase indexes in milk fat. Baumgard et al. [16] demonstrated that the mechanism by which $\mathrm{t} 10, \mathrm{c} 12-\mathrm{C} 18: 2$ decreased these substrate to product ratios involves a reduction in the mRNA abundance of $\Delta^{9}$ desaturase in the mammary gland. During the t10,c12C18:2 infusion, we observed an increase in the saturation of the milk fat of all groups of goats, as indicated by the decrease in the concentration of c9-C16:1 (with no change in C16:0), by the decrease in the concentration of c9-C18:1 and c9,t11-C18:2 and the increase in C18:0. Consistently, there was also an increase in the concentration of the t11-C18:1, with the exception of the goats 
fed the H-CS20 diets. Our results demonstrate that the extent of desaturation of plasma derived $\mathrm{C} 18: 0$ and $\mathrm{t11-C18:1}$ was dramatically decreased by the infusion of 2 g.d ${ }^{-1}$ of $\mathrm{t} 10, \mathrm{c} 12-\mathrm{C} 18: 2$, in line with data from dairy cows infused with high doses of t10,c12-C18:2. We also demonstrated that the desaturation of t11-C18:1 to $\mathrm{c} 9, \mathrm{t} 11-$ $\mathrm{C} 18: 2$ and $\mathrm{C} 18: 0$ to $\mathrm{c} 9-\mathrm{C} 18: 1$ was equally sensitive to $\mathrm{t} 10, \mathrm{c} 12-\mathrm{C} 18: 2$, with a mean reduction of $45 \%$ across diets. When compared to the similar doses of $\mathrm{t} 10, \mathrm{c} 12-\mathrm{C} 18: 2$ infused in dairy cows $\left(\mathrm{g} \cdot \mathrm{kg}^{-1} \mathrm{DMI}\right)$, this reduction in the desaturation index is in agreement with the data of Baumgard et al. [7], but it is much higher than that reported by Baumgard et al. [16] and Loor and Herbein [10] who indicated that the ratios of c9-C18:1 to C18:0 and c9,t11-C18:2 to t11-C18:1 decreased by 6 to $17 \%$ and 12 to $25 \%$, respectively. Moreover, our results also indicate that the decrease in the c9C18:1 concentration and the reduction of c9-C18:1 to C18:0 ratio in milk fat do not appear to be sufficient to reduce milk fat yield in dairy goats. In dairy cows, a reduction in the $\Delta^{9}$ desaturase activity is not necessary to depress the MFC $[7,25]$.

The differences between trials in the reduction in the $\Delta^{9}$ desaturase activity following the $110, \mathrm{c} 12-\mathrm{C} 18: 2$ infusion could be modulated by species differences, stage of lactation, and diet-induced changes in the basal level of its activity. Indeed, the extent of desaturation of C18:0 and t11-C18:1 before the infusion was higher in the milk of the goats fed the CSO diet than in those fed the CS20 diet. This indicates that the $\Delta^{9}$ desaturase activity index was inversely related to c9-C18:1 intake. Consequently, the decrease in the ratio of $\mathrm{c} 9, \mathrm{t} 11-\mathrm{C} 18: 2 / \mathrm{t} 11-$ $\mathrm{C} 18: 1$ or $\mathrm{c} 9-\mathrm{C} 18: 1 / \mathrm{C} 18: 0$ during $\mathrm{t} 10, \mathrm{c} 12-$ C18:2 infusion was lower in the milk of goats fed the CS20 diets, suggesting that the decrease of the $\Delta^{9}$ desaturase activity during t10,c12-C18:2 infusion depends on its basal activity which could be modulated by the FA composition of the diet. Loor and Herbein [10] observed that the reduction in the ratio of $\mathrm{c} 9-\mathrm{C} 18: 1 / \mathrm{C} 18: 0$ and $\mathrm{c} 9, \mathrm{t} 11-$
C18:2/t11-C18:1 in milk during t10,c12C18:2 infusion was not affected by the dietary fat in dairy cows fed high-oleic or highlinoleic oil. These differences are possibly related to the different design of the 2 experiments: during the t10,c12-C18:2 infusion, the diets had a similar FA content in the trial of Loor and Herbein [10], whereas in our experiment, the 2 diets differed for their FA contents.

When no t10,c12-C18:2 was detectable in milk fat (basal value), the goats fed the CS0 diets had higher ratios of c9,t11C18:2/t11-C18:1 or c9-C18:1/C18:0 and a lower concentration of $\mathrm{t} 10-\mathrm{C} 18: 1$ in milk fat than the goats fed the CS20 diets. Independently of the dietary factors, the concentration of t10-C18:1 in milk fat was increased during the $\mathrm{t} 10, \mathrm{c} 12-\mathrm{C} 18: 2$ infusion as observed in dairy cows $[7,16]$. The decrease in desaturase index during t10,c12C18:2 infusion was more marked in the milk fat of the goats fed the CSO diets, probably because their basal value was higher. These data taken together suggest that most of the within-goat variations of the desaturase index observed between basal and t10,c12-C18:2 infusion are inversely related with the variations in $\mathrm{t} 10-\mathrm{C} 18: 1$ in milk fat. It also suggests that the decrease in the activity of $\Delta^{9}$ desaturase observed in our trial during the t10,c12-C18:2 infusion could also be mediated via an indirect mechanism. Possibly, the increase in t10C18:1 availability in the mammary gland due to the t10,c12-C18:2 infusion was directly responsible for the decrease in the activity of $\Delta^{9}$ desaturase. This was in line with data of de Veth et al. [25] who reported no variation in the desaturase index and no increase of $\mathrm{t} 10-\mathrm{C} 18: 1$ in milk fat after the t10,c12-C18:2 infusion. However, this was in contrast with data of Piperova et al. [28] that reported a high concentration of t10C18:1 in milk fat during milk fat depression with no change in the desaturase index, though only total cis-C18:1 was indicated. Moreover, t10,c12-C18:2 but not t10C18:1 decreases $\Delta^{9}$ desaturase activity in mouse liver [29]. Possibly, t10-C18:1 and 
t10,c12-C18:2 may differently affect the activity of $\Delta^{9}$ desaturase according to species (the goat vs. cow).

The DMI, the milk yield, and the yield of milk protein and lactose were not affected by the t10,c12-C18:2 infusion or by the interaction between the dietary factors and the t10,c12-C18:2 infusion. The lack of change in these variables is consistent with most of the studies that have infused a high dose of pure t10,c12-C18:2 isomer $[2,8,10]$ or a high dose of CLA mixture [23].

In conclusion, the infusion of a daily dose of $2 \mathrm{~g}$ of $\mathrm{t} 10, \mathrm{c} 12-\mathrm{C} 18: 2$ isomer of CLA ( $0.07 \%$ of the daily DMI) did not affect the milk fat content or the fat yield of dairy goats. This was related to the lack of reduction in short to medium-chain FA synthesis in the mammary gland. This lack of effect of the t10,c12-C18:2 infusion could be a part of the explanation for the differences between cows and goats in the response to dietary supplementation with poly-unsaturated FA [11-13]. However, the ratio of oleic acid to stearic acid, and rumenic acid to vaccenic acid in milk fat was reduced by the $110, c 12-C 18: 2$ infusion. This reduction in the desaturase index of milk fat could possibly have been mediated via a direct action of t10,c12-C18:2, or an increase in t10-C18:1 availability in the mammary gland. This decrease in desaturase index after t10,c12-C18:2 infusion was not affected by the percentage of concentrate as observed in dairy cows [9], but it was less marked in the goats fed unsaturated FA (mainly oleic acid), possibly because they already had lower basal desaturase index in milk fat. This is in contrast of data in cows which indicated that the inhibitory effect of t10,c12-C18:2 on the desaturation of long chain FA in cows is not affected by a dietary supply of unsaturated FA $[9,10]$.

\section{ACKNOWLEDGMENTS}

The assistance of $\mathrm{H}$. Albarello in the analysis of milk and diet FA is gratefully acknowledged.

\section{REFERENCES}

[1] Yurawecz MP, Roach JAG, Sehat N, Mossoba MM, Kramer JKG, Yu Y. A new conjugated linoleic acid isomer, 7 trans, 9 cis-octadecadienoic acid, in cow milk, cheese, beef and human milk and adipose tissue. Lipids 1998, 33: 803-809.

[2] Baumgard LH, Corl BA, Dwyer DA, Saebo A, Bauman DE. Identification of the conjugated linoleic acid isomer that inhibits milk fat synthesis. Am J Physiol Regul Integr Comp Physiol 2000, 278: R179-R184.

[3] Bauman DE, Corl BA, Baumgard LH, Grinarii JM. Conjugated linoleic acid (CLA) and the dairy cow. In: Garnsworthy PC, Wiseman J. (Eds), Recent Advances in Animal Nutrition, Nottingham University Press, Nottingham, United Kingdom, 2001, p 221-250.

[4] Sackman JR, Ducket SK, Mc Gillis MH, Realini CE, Parks AH, Eggelston RB. Effect of forage and sunflower oil levels on ruminal biohydrogenation of fatty acids and conjugated linoleic acid formation in beef steers fed finishing diets. J Anim Sci 2003, 81: 31743181.

[5] Martin J-C, Valeille K. Conjugated linoleic acids: all the same or to everyone its own function? Reprod Nutr Dev 2002, 42: 525-536.

[6] Giesy JG, Mc Guire MA, Shaffi B, Hanson TW. Effect of dose of calcium salts of conjugated linoleic acid (CLA) on percentage and fatty acids content of milk fat in midlactation Holstein cows. J Dairy Sci 2002, 85: $2023-$ 2029.

[7] Baumgard LH, Langster JK, Bauman DE. Milk fat synthesis in dairy cows is progressively reduced by increasing supplemental amounts of trans-10, cis-12 conjugated linoleic acid (CLA). J Nutr 2001, 131: 17641769.

[8] Peterson DG, Baumgard LH, Bauman DE. Short communication: milk fat response to low doses of trans-10, cis-12 conjugated linoleic acid (CLA). J Dairy Sci 2002, 85: 1764-1766.

[9] Loor JJ, Ferlay A, Doreau M, Chilliard Y. Intestinal supply of trans 10, cis 12-C18:2 lowers milk fat output in Holstein cows fed a highor low-fiber diet with two levels of linseed oil. J Dairy Sci 2002, 85 (Suppl 1): 297.

[10] Loor JJ, Herbein JH. Reduced fatty acid synthesis and desaturation due to exogenous trans10,cis12-CLA in cows fed oleic or linoleic oil. J Dairy Sci 2003, 86: 1354-1369.

[11] Schmidely P, Sauvant D. Taux butyreux et la composition de la matière grasse du lait chez les petits ruminants : effets de l'apport de 
matières grasses ou d'aliment concentré. [Fat content yield and composition of milk in small ruminants: effects of concentrate level and addition of fat.] INRA Prod Anim 2001, 14: 333-352.

[12] Chilliard Y, Ferlay A. Dietary lipid and forage interactions on cow and goat milk fatty acid composition and sensory properties. Reprod Nutr Dev 2004, 44: 467-492.

[13] Chilliard Y, Ferlay A, Rouel J, Lamberet G. A review of nutritional and physiological factors affecting goat milk lipid synthesis and lipolysis. J Dairy Sci 2003, 86: 1751-1770.

[14] Ferlay A, Rouel J, Chabosseau JM, Capitan P, Raynal-Ljutovac K, Chilliard Y. Interactions between raygrass preservation and high-oleic sunflower oil supplementation on goat milk composition, including trans and conjugated fatty acids. In: van der Honing Y (Ed), Wageningen Acad Publ (NL), Book of Abstracts of the 54th Annual Meeting of European Association for Animal Production, Rome, Italy, 31 August-3 September 2003, p 350.

[15] INRA. Ruminant Nutrition. In: Jarrige R. (Ed), Recommended Allowance and Feed Table, INRA, Paris, 1989.

[16] Baumgard LH, Matitashvilli E, Corl BA, Dwyer DA, Bauman DE. Trans 10, cis-12 conjugated linoleic acid decreases lipogenic rates and expression of genes involved in milk lipid synthesis in dairy cows. J Dairy Sci 2002, 85: 2155-2163.

[17] Van Soest PJ, Robertson JB, Lewis BA. Methods for dietary fiber, neutral detergent fiber, and nonstarch polysaccharides in relation to animal nutrition. J Dairy Sci 1991, 74: 35833597.

[18] Folch J, Lees M, Sloane Stanley GA. A simple method for the isolation and purification of total lipids from animal tissues. J Biol Chem 1957, 226: 497-509.

[19] SAS/STAT User's Guide. Release 8th edition 2000. SAS Inst. Inc., Cary, NC.

[20] NRC. In: Natl Acad Sci (Ed), Nutrients Requirements of Goats: Angora, Dairy, and Meat goats in Temperate and Tropical Countries, Washington, DC, 1981.
[21] LeDoux M, Rouzeau A, Bas P, Sauvant D. Occurence of trans-C18:1 fatty acids isomers in goat: effect of two dietary regimens. J Dairy Sci 2002, 85: 190-197.

[22] Loor JJ, Herbein JH. Exogenous conjugated linoleic acids isomers reduce bovine milk fat and yield by inhibiting de novo fatty acid synthesis. J Nutr 1998, 128: 2411-2419.

[23] Chouinard P, Corneau L, Saebo A, Bauman DE. Milk yield and composition during abomasal infusion of conjugated linoleic acids in dairy cows. J Dairy Sci 1999, 82: 2737-2745.

[24] Perfield II JW, Saebo A, Bauman DE. Use of conjugated linoleic acid (CLA) enrichments to examine the effects of trans-8, cis-10 CLA, and cis-11, trans-13 CLA on milk fat synthesis. J Dairy Sci 2004, 87: 1196-1202.

[25] De Veth MJ, Grinarii JM, Pfeiffer AM, Bauman DE. Effect of CLA on milk fat synthesis in dairy cows: comparison of inhibition by methyl esters and free fatty acids, and relationships among studies. Lipids 2004, 39: 365-372.

[26] Mackle T, Kay JK, Auldist MJ, McGibbon AKH, Philpott BA, Baumgard LH, Bauman DE. Effect of abomasal infusion of conjugated linoleic acid on milk fat concentration and yield from pasture-fed dairy cows. J Dairy Sci 2003, 86: 644-652.

[27] Gulati SK, Kitessa SM, Ashes JR, Fleck E, EB Byers, Byers YG, Scott TW. Protection of conjugated linoleic acids from ruminal hydrogenation and their incorporation into milk fat. Anim Feed Sci Technol 2000, 86: 139-148.

[28] Piperova LS, Teter BB, Bruckental I, Sampugna J, Mills SE, Yurawecz MP, Fritsche J, Ku K, Erdman RA. Mammary lipogenic enzyme activity, trans fatty acids and conjugated linoleic acids are altered in lactating dairy cows fed a milk fat-depressing diet. J Nutr 2000, 130: 2568-2574.

[29] Park Y, Storkson JM, Ntamby JM, Cock ME, Sih CJ, Pariza MW. Inhibition of hepatic stearyl-CoA desaturase activity by trans10,cis-12 conjugated linoleic acid and its derivatives. Biochim Biophys Acta 2000, 1486: 285-292. 